\title{
GLOBAL INDIOS
}


NARRATING NATIVE HISTORIES

Series Editors

K. Tsianina Lomawaima

Florencia E. Mallon

Alcida Rita Ramos

Joanne Rappaport

Editorial Advisory Board

Denise Y. Arnold

Charles R. Hale

Roberta Hill

Noenoe K. Silva

David Wilkins

Juan de Dios Yapita

Narrating Native Histories aims to foster a rethinking of the ethical, methodological, and conceptual frameworks within which we locate our work on Native histories and cultures. We seek to create a space for effective and ongoing conversations between North and South, Natives and non-Natives, academics and activists, throughout the Americas and the Pacific region.

This series encourages analyses that contribute to an understanding of Native peoples' relationships with nation-states, including histories of expropriation and exclusion as well as projects for autonomy and sovereignty. We encourage collaborative work that recognizes Native intellectuals, cultural interpreters, and alternative knowledge producers, as well as projects that question the relationship between orality and literacy. 


\section{Global Indios}

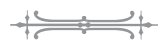

THE INDIGENOUS STRUGGLE

FOR JUSTICE IN

SIXTEENTH-CENTURY SPAIN

Nancy E. van Deusen

Duke University Press

Durham and London 2015 
(C) 2015 Duke University Press

All rights reserved

Printed in the United States of America

on acid-free paper $\infty$

Typeset in Minion Pro by Westchester Publishing Services

Library of Congress Cataloging-in-Publication Data

van Deusen, Nancy E.

Global indios : the indigenous struggle for justice in sixteenth-century

Spain / Nancy E. van Deusen.

pages $\mathrm{cm}$-(Narrating Native histories)

Includes bibliographical references and index.

ISBN 978-0-8223-5847-3 (hardcover : alk. paper)

ISBN 978-0-8223-5858-9 (pbk. : alk. paper)

ISBN 978-0-8223-7569-2 (e-book)

1. Indians - Legal status, laws, etc.-History-16th century.

2. Indians, Treatment of-Spain.

3. Indians, Treatment of-Latin America.

4. Spain-Colonies-America-History-16th century.

5. Spain-History-16th century.

6. Indians-Civil rights.

I. Title. II. Series: Narrating Native histories.

F1411.v363 2015

946'.04-dc23 2014039593

Cover art: Juan Cordero, Christopher Columbus at the Court of Catholic Kings (detail), 1850, oil on canvas, Museo Nacional de Arte. Photo: Scala / Art Resource, N.Y. 
FOR THOSE

WHOSE VOICES

HAVE YET

TO BE HEARD. 
This page intentionally left blank 